\title{
ARTICULATION IN APRAXIA OF SPEECH
}

\author{
BEVERLEY ANN LISTER, B.A. (Sp. \& H. Therapy) (WITWATERSRAND) \\ Psychological and Guidance Services, Transvaal \\ Education Department, Southrand, Johannesburg
}

\begin{abstract}
SUMMARY
In an attempt to show that aphasics with apraxia of speech have characteristic articulatory patterns, two aphasics with apraxia of speech, and one subject with articulatory problems related to his sensory aphasia, underwent articulation testing. A quantitative measure of distance between error sound and target sound showed that the types of aphasics did not differ on distance, and apraxics could therefore not be said to be closer to the target sound than a sensory aphasic. However, the more severe the communication disorder, the higher was the distance score. A qualitative analysis of the data revealed that the apraxics had substitutions of phonemes as their major error, whereas in the subject without apraxia, substitutions were as prevalent as other errors such as reversals, omissions, augmentations. Aphasics with apraxia of speech may be said to show characteristic types of errors.
\end{abstract}

\section{OPSOMMING}

In 'n poging om aan te toon dat afatiese persone met apraksie van die spraak karakteristieke artikulatoriese patrone het, het twee afatiese persone met apraksie van die spraak en een proefpersoon met artikulatoriese probleme verwant aan sy sensoriese afasie, artikulasietoetsing ondergaan. 'n Kwantitatiewe meting van afstand tussen foutiewe klank en doelklank het aangetoon dat afatiese tipes op afstand nie verskil nie; daarom kan daar nie aangeneem word dat die apraktiese persoon nader aan die doelklank is as die persoon met sensoriese afasie nie. Hoe erger die kommunikasiesteuring egter was, hoe hoër was die afstandtelling. 'n Kwalitatiewe analise van die gegewens het openbaar dat waar die apraktiese persone se primêre fout foneemsubstitusie was, by die proefpersoon sonder apraksie daarenteen substitusie net so algemeen voorgekom het as fou te soos omkerings, elisies en toevoegings. Daar kan aangeneem word dat afatiese persone met apraksie van die spraak karakteristieke fou te begaan.

In 1968, Darley ${ }^{7}$ described the field of apraxia of speech as one in which terminological confusion abounded. Eight years later it would appear that there has been no resolution of this confusion, this writer finding in the literature more than 15 different terms for the manifestations of an apraxia of speech. These include cortical dysarthria, ${ }^{1}$ phonetic disintegration, ${ }^{29}$ apraxía dysarthria, ${ }^{24}$ articulatory apraxia, ${ }^{11}$ oral apraxia,${ }^{10}$ facial apraxia, ${ }^{12}$ verbal apraxia, ${ }^{32,33}$ sensory-motor impairment, ${ }^{25,28}$ pure motor aphasia, ${ }^{3}$ and afferent kinesthetic aphasia. ${ }^{20}$ These reflect the diverse modes of thinking among writers. It also reflects to some extent how apraxia, dysarthria and aphasia are inter-related and how some authors have found it difficult to differentiate one from the other, seeing aspects of one in the other, elg. apraxia dysarthria, afferent kinesthetic aphasia. Apraxia often accompanies motor aphasia, $3,10,12,33$ and the writer is of the opinion that this may have contributed to the difficulty of separating at least these two from each other. Dysarthria may also accompany 
apraxia $^{9,24}$ and it has been reported that apraxia of speech is occasionally found with sensory aphasia. ${ }^{4,5,9}$

Recently, apraxia of speech has been defined as a non-linguistic sensory-motor disorder of articulation characterized by impaired ' . . . capacity to program the positioning of the speech musculature and the sequencing of muscle movements for volitional production of phonemes. ${ }^{26}$ This definition appears to be fairly comprehensive, and is the one accepted by the writer. Martin, ${ }^{21}$ however, feels that apraxia of speech cannot be non-linguistic, while others ${ }^{17,34}$ prefer to think of apraxia as a purely motor disorder without sensory involvement.

Despite the disagreement and confusion in studies in apraxia of speech, certain characteristics do emerge as fairly well agreed upon in the literature:

1. There is absence of significant weakness, paralysis and inco-ordination of the speech apparatus. ${ }^{7}$

2. As a result of the disturbed motor speech programming, ${ }^{4,5}$ apraxics grope for the correct positions of the articulators ${ }^{7,8,9}$ and the result is often omission, substitution or distortion of the phonemes. $9,17,20,28$

3. Errors are inconsistent, ${ }^{7,9}$ and are not 'blind', i.e. their articulation attempts usually approximate the desired sound closely. ${ }^{5,32}$

ln order to describe to what extent errors do approximate the target phoneme, Trost and Canter ${ }^{32}$ calculated the distance of the error sounds of apraxics on a 4-feature system of place, manner, voicing and oral/nasal emission. However it is felt that this system of analysis could not give a true reflection of 'closeness' by virtue of the fact that on this scale voiced/voiceless, a two-dimensional category, is weighted equally with a manner or place category which has 6 alternatives in English. Lecours and Lhermitte ${ }^{19}$ carried out a similar analysis on the speech of jargon aphasics and found similar results to Trost and Canter, ${ }^{32}$ i.e. that jargon aphasics also closely approximated their target sound. The method of analysis of the data was probably a factor in these seemingly contradictory results. Martin and Rigrodsky ${ }^{22}$ further confused the issue by apparently considering the latter two experiments as being ones in which the same kinds of subjects (Ss) were tested. Canter, ${ }^{4}$ however, has claimed that aphasics with apraxia of speech are closer in distance to the target sound than sensory aphasics. The writer felt there was thus an indication for the need to study the articulation errors of both apraxics and aphasics without apraxia, using a common and more sensitive method of analysis.

\section{METHOD}

\section{HYPOTHESES}

1. Apraxics of speech are closer in distance to the target sound than are aphasics with articulation problems other than apraxia of speech.

2. A qualitative analysis of speech utterances will reveal differences between apraxics and aphasics with other kinds of articulation trends.

\section{CRITERIA FOR SUBJECT SELECTION}

The limited number of Ss available necessitated broad criteria of selection. All Ss were required to be: 
1. Aphasic, as diagnosed by a speech therapist and a neurologist and further assessed as such by the experimenter (E) and results of the Boston Diagnostic Aphasia Examination. ${ }^{14}$

2. Physically able to undergo testing.

3. Reported to have articulatory difficulties and/or an apraxia by their speech therapists.

\section{SUBJECTS}

Three aphasic Ss participated in the study. Relevant information concerning the Ss is tabulated in Table 1.

\begin{tabular}{|c|c|c|c|}
\hline Subjects & Mrs M & Mrs K & $\mathrm{Mr} \mathrm{G}$ \\
\hline Sex & Female & Female & Male \\
\hline Age & 45 & 25 & 68 . \\
\hline $\begin{array}{l}\text { Handedness } \\
\text { Before }\end{array}$ & Right & Right & Right \\
\hline At present & Left & Right & Right \\
\hline $\begin{array}{l}\text { Previous } \\
\text { Occupation }\end{array}$ & Manicurist & Housewife & $\begin{array}{l}\text { Self em- } \\
\text { ployed in } \\
\text { Mining Field }\end{array}$ \\
\hline $\begin{array}{l}\text { Present } \\
\text { Occupation }\end{array}$ & Unemployed & Housewife & Unemployed \\
\hline $\begin{array}{l}\text { Level of } \\
\text { Education }\end{array}$ & Std 8 & Std 8 & Matric \\
\hline $\begin{array}{l}\text { Date of } \\
\text { Onset }\end{array}$ & July 1974 & May 1975 & June 1972 \\
\hline Therapy & $\begin{array}{l}\text { Since } \\
\text { July } 1974\end{array}$ & $\begin{array}{l}\text { None at } \\
\text { testing }\end{array}$ & $\begin{array}{l}\text { Since } \\
\text { July } 1972\end{array}$ \\
\hline Etiology & $\begin{array}{l}\text { Vascular. } \\
\text { Arterio- } \\
\text { sclerosis } \\
\text { in carotid } \\
\text { artery } \\
\text { Hypercholes- } \\
\text { terolemic. }\end{array}$ & $\begin{array}{l}\text { Vascular. } \\
\text { Occlusion. } \\
\text { in branch } \\
\text { of middle } \\
\text { cerebral } \\
\text { artery after } \\
\text { childbirth. } \\
\text {. }\end{array}$ & $\begin{array}{l}\text { Vascular.' } \\
\text { Embolus to } \\
\text { left parietal } \\
\text { cortex. } \\
\text { History of } \\
\text { high blood } \\
\text { pressure, } \\
\text { fibrillations. }\end{array}$ \\
\hline
\end{tabular}

TABLE I: Relevant information from Case Histories of Aphasic Subjects. 


\section{APPARATUS AND PROCEDURE}

The number of sessions with each patient varied in accordance with the severity of the problem. Where the communication handicap was more severe it was necessary to have shorter, more frequent interviews, to reduce the element of fatigue. In addition the $\mathrm{E}$ had to be fairly flexible in administering the tests in order that the Ss would not become traumatized by failure.

\section{TESTS ADMINISTERED:}

A. The Boston Diagnostic Aphasia Examination ${ }^{14}$ as it gives a comprehensive profile of patients on all levels of higher cortical functioning.

B. Articulation tests.

Trost and Canter ${ }^{32}$ used the Templin-Darley test of articulation. ${ }^{30} \mathrm{E}$ was of the opinion that the black and white pictures used in this test were not suitable for aphasic patients as they detracted from the clarity of the object depicted. In addition, many of the pictures depicted objects more common in America, or representing Americanisms, e.g. gopher, sled.

The test devised by $E$ consisted of 61 words, representing the 24 phonemes of English in initial, medial and final position. Common monosyllabic words which could easily be portrayed were chosen. The clear, simple pictures were displayed on 4 " by 3 " cards. It was not possible to meet all the criteria in regard to certain phonemes in the medial position, and 2 or 3 syllabic words had to be used, e.g. medial $/ \mathrm{b} /=$ rabbit, medial $/ \widehat{\mathrm{t}} / \mathrm{f}$ $=$ matches. 59 of the words used appeared in the Thorndike-Lorge list of 30,000 common words. ${ }^{31}$ Those not appearing were 'pram' and 'mealie', mealie being the South African word for maize which did appear in the list and pram a word which is in common use now, but might not have been in 1931 when the list was devised.

It was felt that if certain stimulus conditions were found to be more favourable than others in eliciting responses, this could have important implications for therapy. In addition, the type of $S$ and the influence of the stimulus conditions on them might reveal interesting findings. Thus the articulation test was administered over 5 conditions:

1. Naming the pictures.

2. Naming the pictures with the word printed underneath in 1 inch black lettering.

3. Naming the picture with the E simultaneously presenting a related sentence auditorily with each picture.

4. Naming the picture with the sentence presented auditorily and the word printed beneath.

5. Naming the picture with the model given by $\mathbf{E}$ i.e. on imitation.

All responses were recorded on a National tape recorder (Model R.Q. 7065). The pictures were so arranged that initial, medial and final position phonemes were randomly distributed through the sample. Each $S$ was tested in the same order of conditions, i.e. the order listed above. The test was not given over more than two conditions in one session in order to control to some extent for practice effect. 
In order to measure the degree of similarity or distance between any two phonemes, the phonemes were described in terms of their distance features and these features were then divided into 2 sections, those comprising manner of articulation (See Figure 1 ) and those comprising place (See Figure 2). It has been stated in the literature that place errors are the most common in the speech of apraxics. ${ }^{25,32}$

\begin{tabular}{|c|c|c|c|c|c|c|c|c|c|c|c|c|c|c|c|c|c|c|c|c|c|c|}
\hline & $\mathrm{p}$ & $t$ & $\mathrm{~h}$ & $\check{c}$ & $\mathrm{k}$ & b & $\mathrm{d}$ & $\begin{array}{lll}\mathrm{j} & \mathrm{g}\end{array}$ & ; & $\theta$ & $\mathrm{s}$ & $\check{s}$ & $\mathbf{v}$ & b & 2 & $\check{z}$ & \begin{tabular}{l|l}
1 & $\mathrm{r}$
\end{tabular} & $\mathrm{m}$ & $\mathrm{n}$ & $\eta$ & w & $\mathrm{y}$ \\
\hline Nasal & - & - & - & & - & - & - & -- & $-1-$ & $-1-$ & - & - & - & - & -1. & - & $-1-$ & -+ & + & + & - & - \\
\hline Voice & - & - & - & - & - & + & + & $+t$ & - & - & - & - & + & + & + & + & & ++ & + & + & + & . \\
\hline $\begin{array}{l}\text { Continu- } \\
\text { ant }\end{array}$ & - & - & + & - & - & - & - & -- & -1 & + & ++ & + & + & + & + & + & ++ & +- & - & - & + & + \\
\hline $\begin{array}{l}\text { Delayed } \\
\text { Release }\end{array}$ & - & - & - & + & - & - & & +- & - & - & - & - & - & -- & - & - & $-1-$ & -- & - & - & - & - \\
\hline $\begin{array}{l}\text { Conso- } \\
\text { nantal }\end{array}$ & + & + & - & + & + & + & + & + & + & + & ++ & + & + & + & + & + & ++ & $+1+$ & +1 & + & - & .. \\
\hline Vocalic & - & - & - & - & - & - & - & -- & - & - & - & -- & - & - & - & - & ++ & +- & -1 & - & - & 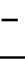 \\
\hline Strident & - & - & - & + & -1 & - & 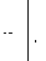 & +- & - & - & -+ & + & + & -1 & + & + & -- & -- & - & - & - & \\
\hline
\end{tabular}

Figure 1: Distinctive features of manner of articulation of the Consonant phonemes of English

\begin{tabular}{|c|c|c|c|c|c|c|c|c|c|c|c|c|c|c|c|c|c|c|c|c|c|c|c|c|}
\hline & $\mathrm{p}$ & $\mathrm{t}$ & h & $\check{c}$ & $\mathrm{k}$ & b & d & $\mathrm{j}$ & $\mathrm{g}$ & f & $\theta$ & $\mathrm{s}$ & š & $\mathrm{v}$ & $d$ & $i$ & z & 1 . & \begin{tabular}{l|l}
$r$ & 1
\end{tabular} & $\mathrm{~m}$ & $\mathrm{n}$ & n' & $\mathrm{w}$ & $y$ \\
\hline Coronal & - & + & - & + & - & -1 & + & + & - & - & + & + & + & - & + & + & + & + & + & - & + & - & - & - \\
\hline Anterior & + & + & - & - & - & + & + & - & - & + & + & $\begin{array}{llll}+ & l & l\end{array}$ & - & + & + & $\begin{array}{llll}+ & & l & -1\end{array}$ & - & + & - & + & + & - & + & - \\
\hline Back & - & - & - & - & + & - & - & - & + & - & - & - & - & - & - & - & - & - & - & - & - & + & - & - \\
\hline High & - & - & - & + & + & - & - & + & + & - & - & - & + & - & - & - & + & - & - & - & - & + & - & + \\
\hline Lateral & - & - & - & - & - & - & - & - & - & - & - & 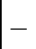 & -1 & - & - & - & - & + & - & - & -. & - & - & - \\
\hline
\end{tabular}

Figure 2: Distinctive Features of place of the consonant phonemes of English

Two tables were then drawn up to calculate the difference betweén each phoneme. Table II shows distances of place and Table III shows distances of manner.

From these tables, for example, the distance between $/ f /$ and $/ \theta /$ may be said to be 1 , i.e. $/ f /$ is minus $(-)$ coronal, whereas $/ \theta /$ is plus $(+)$ coronal while they do not differ on other features of place. Theylare also a distance of 1 apart on manner, as $/ \mathrm{f} /$ is + strident and $|\theta|-$ strident. $^{27}$ Thus it was possible to quantitatively state the difference between error sound and target sound in the responses on the articulation tests. 


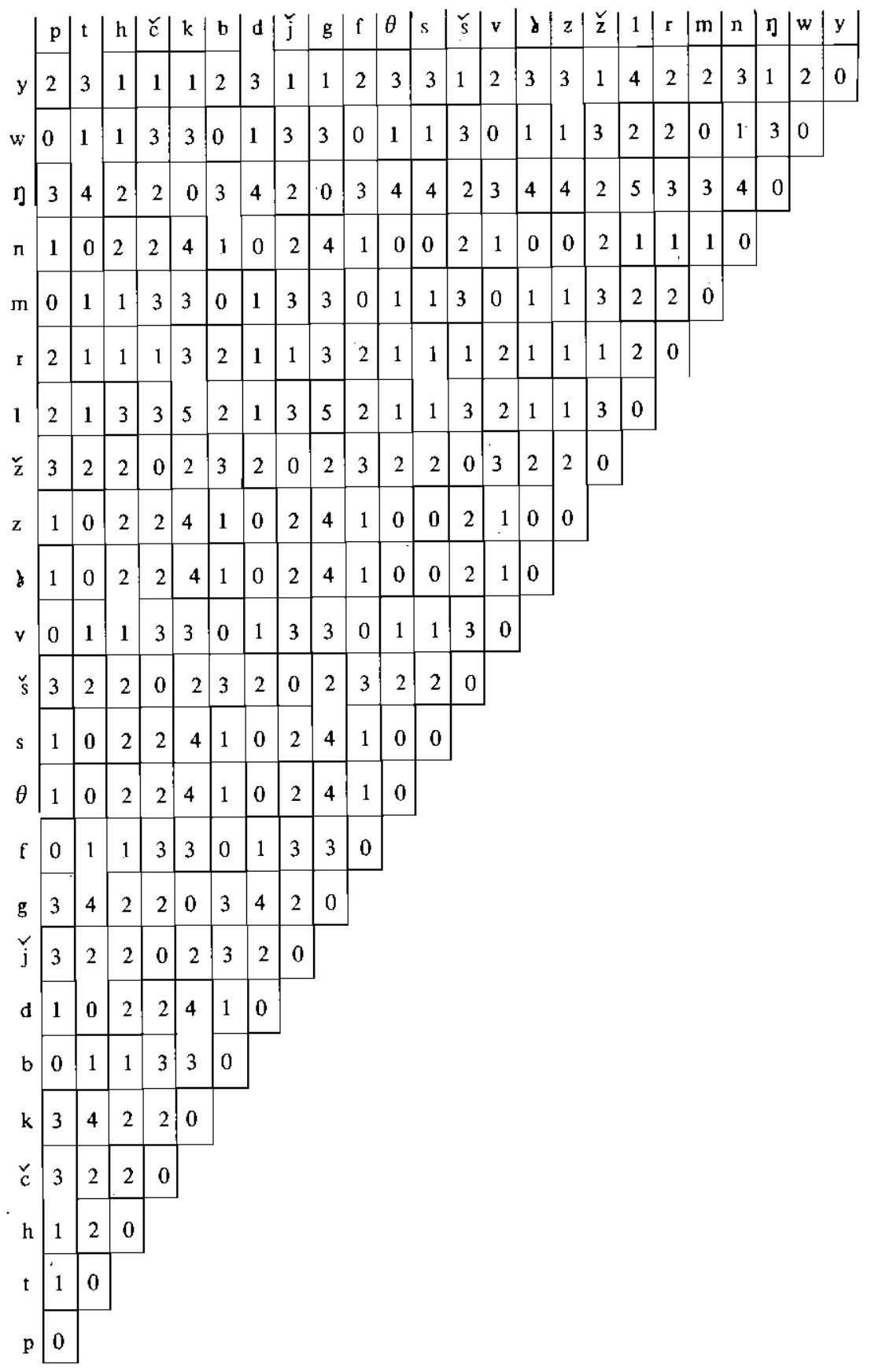

TABLE Il: Measures of Distance in place of articulation between the consonant phonemes of English 


\begin{tabular}{l|l|l|l|l|l|l|l|l|l|l|l|l|l|l|l|l|l|l|l|l|l|l|l|l|}
$\mathrm{y}$ & $\mathrm{p}$ & $\mathrm{t}$ & $\mathrm{h}$ & $\breve{c}$ & $\mathrm{k}$ & $\mathrm{b}$ & $\mathrm{d}$ & $\breve{\mathrm{j}}$ & $\mathrm{g}$ & $\mathrm{f}$ & $\boldsymbol{\theta}$ & $\mathrm{s}$ & $\breve{s}$ & $\mathrm{v}$ & $\mathrm{r}$ & $\mathrm{z}$ & $\breve{z}$ & $\mathbf{1}$ & $\mathrm{r}$ & $\mathrm{m}$ & $\mathrm{n}$ & $\mathrm{g}$ & $\mathrm{w}$ & $\mathrm{y}$ \\
\hline & 3 & 3 & 1 & 5 & 3 & 2 & 2 & 4 & 2 & 3 & 2 & 3 & 3 & 2 & 1 & 2 & 2 & 2 & 2 & 3 & 3 & 3 & 0 & 0 \\
\hline & 3 & 3 & 1 & 5 & 3 & 2 & 2 & 4 & 2 & 3 & 2 & 3 & 3 & 2 & 1 & 2 & 2 & 2 & 2 & 3 & 3 & 3 & 0 &
\end{tabular}

y 2 \begin{tabular}{lllllllllll|l|l|l|l|l|l|l|l|l|l|l|l|l|}
\hline & 2 & 4 & 4 & 2 & 1 & 1 & 3 & 1 & 4 & 3 & 4 & 4 & 3 & 2 & 3 & 3 & 3 & 3 & 0 & 0 & 0 \\
\hline
\end{tabular}

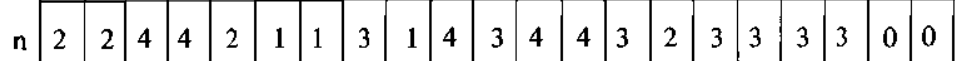

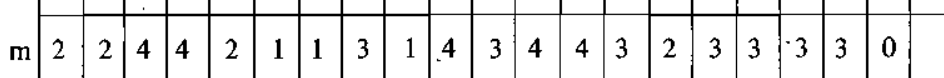

r 3 \begin{tabular}{l|lllllllllllllllllllllll|l|}
\hline 3 & 3 & 3 & 5 & 3 & 2 & 2 & 4 & 2 & 3 & 2 & 3 & 3 & 2 & 1 & 2 & 2 & 0 & 0 \\
\hline
\end{tabular}

\begin{tabular}{lllllllllllllllllll|l|l|l|l|l|}
\hline 1 & 3 & 3 & 3 & 5 & 3 & 2 & 2 & 4 & 2 & 3 & 2 & 3 & 3 & 2 & 1 & 2 & 2 & 0 \\
\hline
\end{tabular}

\begin{tabular}{llllllllllllllllllllllll}
\hline$z$ & 3 & 3 & 3 & 3 & 3 & 2 & 2 & 2 & 2 & 1 & 2 & 1 & 1 & 0 & 1 & 0 & 0 \\
\hline
\end{tabular}

\begin{tabular}{ll|l|l|l|l|l|l|l|l|l|l|l|l|l|l|l|}
\hline 2 & 3 & 3 & 3 & 3 & 3 & 2 & 2 & 2 & 2 & 1 & 2 & 1 & 1 & 0 & 1 & 0 \\
\hline
\end{tabular}

\begin{tabular}{lllllllllll|l|l|l|l|l|l|l|l|}
\hline$j$ & 2 & 2 & 2 & 4 & 2 & 1 & 1 & 3 & 1 & 2 & 1 & 2 & 2 & 1 & 0 \\
\hline
\end{tabular}

\begin{tabular}{llllllllllllllllll|l|}
\hline & 3 & 3 & 3 & 3 & 3 & 2 & 2 & 2 & 2 & 1 & 2 & 1 & 1 & 0 \\
\hline
\end{tabular}

\begin{tabular}{lllllllllllllllllll}
\hline & 2 & 2 & 2 & 2 & 2 & 3 & 3 & 3 & 3 & 0 & 1 & 0 & 0 &
\end{tabular}



\begin{tabular}{lllllll|l|l|l|l|l|l|}
\hline$\theta$ & 1 & 1 & 1 & 3 & 1 & 2 & 2 & 4 & 2 & 1 & 0 \\
\hline
\end{tabular}

$\begin{array}{lllllllllllllll}\text { f } & 2 & 2 & 2 & 2 & 2 & 3 & 3 & 3 & 3 & 0 & \end{array}$

$\begin{array}{llllllllllllllll}\mathbf{f} & 2 & 1 & 1 & 3 & 3 & 1 & 0 & 0 & 2 & 0 & \end{array}$



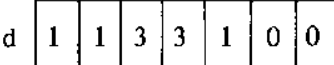

b

\begin{tabular}{ll|lllll}
1 & 1 & 3 & 3 & 1 & 0 \\
\hline
\end{tabular}

k $\begin{array}{lllllll}0 & 0 & 2 & 2 & 0\end{array}$



h

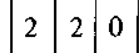



p 0

TABLE III: Measures of Distance of Manner of Articulation between the consonant Phonemes of English 
This method was chosen in preference to those described by some authors. ${ }^{16,19,32}$ As has been discussed, their measures were not felt to reflect distance adequately. A similar method to the one used in this study was used by Martin and Rigrodsky, ${ }^{23}$ but it was not utilised here because they did not differentiate between place and manner features, a distinction which $\mathrm{E}$ felt might yield an important differentiating factor between aphasics with apraxia of speech and aphasics with other kinds of articulation problems.

The distance scale could not be used when:

1. Ss substituted a consonant cluster for a phoneme, e.g. klaiən/laiən.

2. Ss omitted the target phoneme.

3. Ss substituted an associated word for the target word e.g. bluu/yElou.

4. When the $S$ was obviously perseverating.

5. When $S$ s used a jargon word which could not be related to the target word by $\mathrm{E}$.

When these words were eliminated from the data it was no longer possible to have a straight comparison of total distance scores in different categories, e.g. initial, medial and final, as there was an unequal number of words in the different groups. All scores were then converted to the percentage of incorrect features of the total number of possible features. The total number of features possible was the number of phonemes under consideration multiplied by the number of features used, i.e. 12 (See Figures 1 and 2). Scores could then be compared.

The number of errors made varied between Ss. To test whether aphasics with apraxia of speech are closer in distance to the target sound than are aphasics with articulation problems other than apraxia of speech (in this case a sensory aphasic, as diagnosed on the Boston Examination), Ss were only compared on phonemes where both had made errors; thus Mr G and Mrs M were compared on 31 utterances, Mr G and Mrs $\mathrm{K}$ on 7, and Mrs M and Mrs K on 7 utterances.

In accordance with Hypothesis 2, all the data from the articulation testing were qualitatively assessed and occurrence of characteristics such as perseverations, reversals, word and sound substitutions, simplifications and augmentations were noted.

\section{RESULTS AND DISCUSSION}

A. THE BOSTON DIAGNOSTIC APHASIA EXAMINATION ${ }^{14}$

In terms of the classificatory system of the authors, the examination yielded the following profiles.

1. Mr G: A profile of Wernicke's aphasia with the 'most critical features ... (of) impaired auditory comprehension and fluently articulated, but paraphasic speech', with reading and writing severely impaired as well. On the aphasia severity rating scale he received a rating of 2 , which is described as follows: ‘. . frequent failures to convey the idea, but patient shares the burden of communication with the examiner' ${ }^{14}$ In this paper, Mr G will be referred to as a sensory aphasic, and is understood to have articulatory problems not due to an apraxia of speech. 
2. Mrs M: A profile of conduction aphasia where the '... outstinding speech difficulty is in the proper choice and sequencing of their phonemes, so that literal paraphasia constantly interferes with production'. ${ }^{14}$ Repetition is impaired, auditory comprehension is high, and reading and writing scores are also somewhat depressed. Mrs $\mathrm{M}$ was also rated a score of 2 on the severity rating scale. Goodglass and Kaplan ${ }^{14}$ equate conduction aphasia with Luria's afferent motor aphasia, which he describes as a disturbance of the ability to articulate and to use speech when primary oral movements are intact ${ }^{20}$ Luria feels that to consider the disorder of motor aphasia in relation to the motor disorder of apraxia is a progressive step and he in fact uses the term of apraxia specifically in connection with afferent motor aphasia. In this paper conduction aphasia ${ }^{14}$ and afferent motor aphasia ${ }^{20}$ will be referred to as an apraxia of speech.

3. Mrs K: Her profile also appeared to correspond with that of the conduction aphasia described above, although scores were less depressed and she received a severity rating of 4 - described as 'some obvious loss of fluency in speech ... without significant limitation on ideas expressed of form of expression'. 4

\section{B. ARTICULATION TESTS}

Distance measured between Mrs $\mathrm{M}$ and $\mathrm{Mr} \mathrm{G}$ over 31 utterances showed that there was only a small difference in the number of feature errors produced, Mrs M having 102 errors, while Mr G had 106 errors. The difference between Mrs $\mathrm{K}$ and Mrs $\mathrm{M}$ was much large, despite the fact that both had been diagnosed as having apraxia of speech. The difference in the number of feature errors between Mrs K and Mr G was 14, as opposed to the 11 point difference between Mrs $\mathrm{K}$ and $\mathrm{Mrs} \mathrm{M}$; indicating that $\mathrm{Mr} \mathrm{G}$ and Mrs $\mathrm{M}$ were at a similar distance from Mrs $\mathrm{K}$ on feature errors. Results are shown in Table IV. From these results, it may be postulated that it is not the disorder itself which results in a farther or closer distance from the target sound, but the severity of the disorder. Mrs $\mathbf{K}$ had been rated as having only a mild impairment on the Boston Examination, whereas Mrs M and Mr G had been rated equally on the severity rating scale. Of interest were the similar and sometimes identical errors of the Ss, e.g. Mrs $\mathrm{M}$ and $\mathrm{Mrs} \mathrm{K}$ respectively:



These results appear to clarify, to some extent, distance scores. It was not closeness to the target that was the most important differentiating factor in articulation, for all could be demonstrated as making similar errors, but it was the total number of words which contained errors directly related to severity that was important.

Individual scores show that for Mrs $\mathrm{K}$ the naming task was most difficult, and the cueing, especially involving some auditory stimulus, facilitated the correct response. She had the greatest number of errors in medial position and more 


\begin{tabular}{|c|c|c|c|c|}
\hline $\begin{array}{c}\text { Number of } \\
\text { Utterances }\end{array}$ & Subject & Place & Manner & Distance Total \\
\cline { 1 - 2 } 31 & Mr. G & 47 & 59 & 106 \\
& Mrs. M & 54 & 48 & 102 \\
\hline \multirow{2}{*}{7} & Mrs. M & 15 & 12 & 27 \\
& Mrs. K & 5 & 11 & 16 \\
\hline & Mrs. K & 5 & 8 & 13 \\
7 & Mr. G & 11 & 16 & 27 \\
\hline
\end{tabular}

TABLE IV: Between S comparison of total distances of error sounds from target sound

errors of feature of manner than of place. She experienced least difficulty in phonemes in initial position. See Table V.

\begin{tabular}{|c|c|c|c|c|c|c|}
\hline & $\begin{array}{l}\text { Naming } \\
\text { Picture }\end{array}$ & $\begin{array}{l}\text { Picture } \\
\text { and } \\
\text { Printed } \\
\text { Word }\end{array}$ & $\begin{array}{l}\text { Picture } \\
\text { and } \\
\text { Auditory } \\
\text { Stimulus }\end{array}$ & $\begin{array}{l}\text { Picture } \\
\text { Word and } \\
\text { Auditory } \\
\text { Stimulus }\end{array}$ & $\begin{array}{l}\text { Picture } \\
\text { and } \\
\text { Imitation }\end{array}$ & Total \\
\hline Initial & ,49 & 0 & 0 & 0 & 1,85 & ,47 \\
\hline Medial & 1,96 &, 93 & 1,39 & 2,31 & 0 & 1,14 \\
\hline Final & 3,24 & 0 & ,93 & 0 & 0 &, 83 \\
\hline $\begin{array}{l}\text { Total \% } \\
\text { errors }\end{array}$ & 1,92 & ,31 & ,47 & ,79 & ,62 & \\
\hline $\begin{array}{l}\text { No. featl } \\
\text { errors }\end{array}$ & \multicolumn{6}{|c|}{$=26$. Comprising 6 place errors and 20 manner errors } \\
\hline
\end{tabular}

TABLE V: Total distance scores expressed as the percentage of incorrect features: Mrs K.

Mrs $\mathrm{M}$ also had greater difficulty in the naming task and responses on imitation were somewhat better than those following other forms of cueing. (See Table VI). The latter seemed to facilitate responses more or less equally. The results over the different situational variables support the findings of Johns and Darley, ${ }^{17}$ who found that mode of stimulus presentation affected the articulatory performance of apraxics, as opposed to Deal and Darley ${ }^{9}$ who found that situational variables had no effect on phonemic accuracy. Mrs M also had more difficulty on phonemes in medial position. Although most studies have reported that initial position is the most difficult for apraxics of speech, ${ }^{5,8,29,32}$ a study by La Pointe ${ }^{18}$ did find, as did Johns and Darley, ${ }^{17}$ that no single position in a word was characteristically more difficult. 


\begin{tabular}{|c|c|c|c|c|c|c|}
\hline & $\begin{array}{l}\text { Naming } \\
\text { Picture }\end{array}$ & $\begin{array}{l}\text { Picture } \\
\text { and } \\
\text { Printed } \\
\text { Word }\end{array}$ & $\begin{array}{l}\text { Picture } \\
\text { and } \\
\text { Auditory } \\
\text { Stimulus }\end{array}$ & $\begin{array}{l}\text { Picture } \\
\text { Word and } \\
\text { Auditory } \\
\text { Stimulus }\end{array}$ & $\begin{array}{l}\text { Picture } \\
\text { and } \\
\text { Imitation }\end{array}$ & Total \\
\hline Initial & 12,18 & 7,35 & $4,4^{\circ}$ & 5,56 & & 6,83 \\
\hline Medial & 17,26 & 1,04 & 3,92 & 6,37 & 7,8 & 7,8 \\
\hline Final & 1,96 & 5,09 & 3,7 & 1,56 & 2,3 & 2,97 \\
\hline $\begin{array}{l}\text { Total \% } \\
\text { errors }\end{array}$ & 9,85 & 4,55 & 4,01 & 4,58 & 5,28 & \\
\hline
\end{tabular}

TABLE VI: Total distance scores expressed as the percentage of incorrect features : Mrs M.

It is important to note that words in which medial position was tested were longer and had more syllables than those in which initial and final position were tested. It has been claimed that apraxics are negatively affected by word length, ?,9,17,28 and find polysyllabic words more difficult than monosyllabic. ${ }^{8}$ Thus, scores in this area might have been a reflection of these factors, and not the position of the phoneme as such. However, by virtue of its position, a medial phoneme implies a transition from one phoneme to another, and is often in the position V C V. Apraxics of speech are felt to have difficulty in transitions in the co-ordinated sequencing of several articulators, ${ }^{3,5,28,29}$ and this would support the finding that a phoneme in the medial position presents more difficulty.

Mrs $\mathrm{M}$ demonstrated the same number of place errors as errors of manner of articulation, while Mrs K, as mentioned above, had more manner errors than those of place. These results are contrary to those of Trost and Canter ${ }^{32}$ and Osgood and Miron ${ }^{25}$ who considered errors of place to be most common. The limited number of Ss and the fact that their results were dissimilar introduced a limitation with regard to drawing any conclusions from these results. An important factor in obtaining different results from those reported in the literature, is the different form of analysis used in this study. One point of difference is that voicing is considered an aspect of manner, whereas in other studies, ${ }^{16,19,32}$ it has been rated as a separate category. This in itself may have affected the results significantly.

Mr G's greatest difficulty occurred on the naming task, and on naming with an auditory stimulus, with the latter presenting slightly more difficulty. (See Table VII) It appeared that his responses were often influenced by the sentence which the $E$ had given together with the presentation of the picture. The phonemes from the more significant word's in the given sentence found their way into his response. The added cue of the printed word seemed to have the effect of overcoming this intrusion to some extent, as he concentrated on the 
visual image. He had almost equal difficulty with phonemes, whether they occurred in initial, medial or final positions, with slightly more difficulty on final position. Martin and Rigrodsky ${ }^{22}$ emphasize the difficulty of final position for aphasics, but there is little other evidence of such findings in the literature. Mr G had more place errors than those of manner, and this is consistent with findings of other studies of sensory aphasics. ${ }^{15,13}$

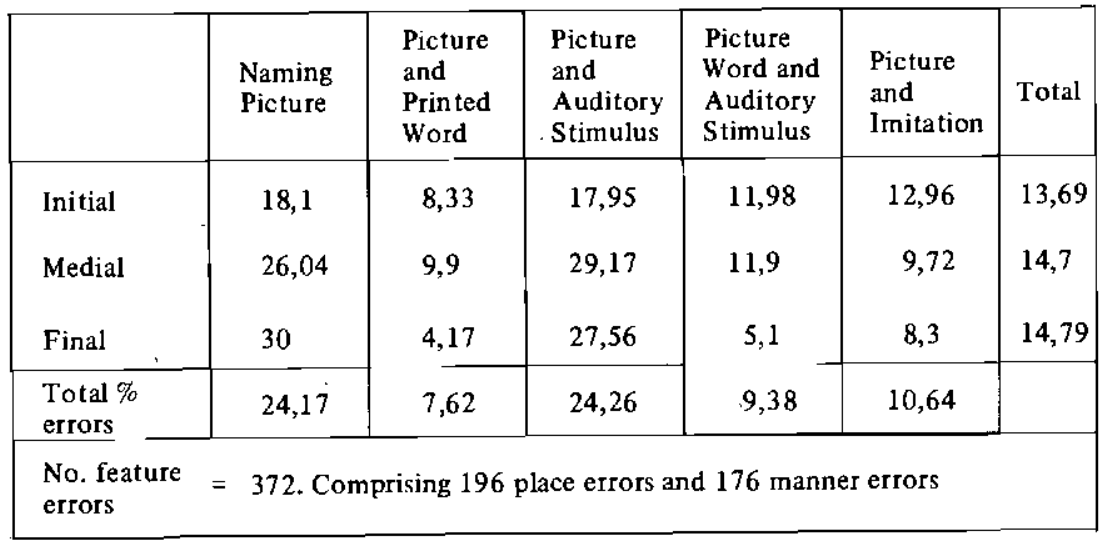

TABLE VII Total distance scores expressed as the percentage of incorrect features: $\mathrm{Mr} \mathrm{G}$.

In analysis of types of errors produced, some trends emerged. Mrs $\mathrm{K}$ tended to reduce affricates, either to their fricative component or more often, to their stop component, e.g. d/dz. Fricatives were sometimes complicated by making them affricates, e.g. $+\int / \int$, and she frequently made an error of voiced/voiceless, e.g. $\mathrm{k} / \mathrm{g}, \mathrm{p} / \mathrm{b}$, and $\mathrm{z} / \mathrm{s}$. Nasals $/ \mathrm{m} /, \mathrm{n} /$ and $/ \mathrm{h} /$ were often confused. In terms of categories of stop, fricative, nasal, resonants, Mrs $\mathrm{K}$ was not observed to make confusion between categories, but only between phonemes within these categories, e.g. 1/r. The category of affricate, by definition, consists of both a stop and a fricative quality, and it was only between the categories of stop and fricative across affricate that Mrs $\mathrm{K}$ substituted phonemes across categories, e.g. $+/ \mathrm{f} f$. Omissions were also present in her speech, e.g. $z E b \Lambda / z E b r \Lambda$. In Mrs M's responses, trends were less clear. Although her errors tended to be within the categories mentioned above, she had frequent substitutions across categories, e.g. $t / m, g / n, g / v, w / l, r / d$. She also made errors of voiced/voiceless features, e.g. $p / b$, but these were not as frequent as some other errors. She had difficulty with nasals, which supported a finding of Shankweiler and Harris ${ }^{29}$ in their study of apraxics of speech. She also experienced difficulty with affricates and confusion among fricatives, as did Mrs K. This difficutly with fricatives and affricates seems to be a finding which is well supported by other studies. ${ }^{8,9,18,29}$ Mrs M also demonstrated omissions e.g. pæm/præm, dæef/d 3 əraəf as well as complication of sounds $s k r / s, \hat{t} \int / t$, as Mrs $K$ had done. An interesting phenomenon in Mrs M's speech was the introduction of $/ 1 /$ and $/ r /$ into a CVC structure, making it CCVC. It appeared that these phonemes were used 
as 'helpers' to facilitate the transition from a consonant to a vocoid. That these sounds may facilitate the transition is supported by the fact that $/ 1 /$ and $/ r /$ are the only two consonants which have vocoid properties. Examples of the use of

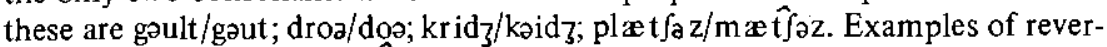
sals of letters were $\int \mathrm{op} / \mathrm{wot} \hat{\int}$ and dzæslə/saldz̧ə and perseveration of letters -

mimiz/miliz; rariəu/raidiou. Generally, the error demonstrated most frequently by the apraxics was one of substitution which is in agreement with the observations made by a number of workers. ${ }^{8,9,20}$ Errors of augmentation of phonemes, and omissions were present to a lesser extent, while reversals and perseverations were relatively rare. Anticipations were not observed in the apraxics.

$\mathrm{Mr}$ G's responses, however, were characterized by numerous neologisms, e.g. taundəl/dzəraəf; verbal paraphasias, e.g. donki/zEbr^; bluu/yEləu; reversals, puus/suup; kEnz/nEst; kəit/raik; and perseverations, e.g. faul, faulə, fauzəl. He did not demonstrate perseverations on a phoneme level as Mrs M. had done. Anticipations which occurred were fEləfaun/tEləfəun; $p \times p / t æ p$. He also showed omissions e.g. fEəz/fEdəz and augmentations, e.g. kıpət/kıp. His substitution errors were both of the within and between category kind. He tended to pluralize a number of words, e.g. pigz/pig; b3dz/b3d; bolz/bol when there was only one object depicted. He frequently responded with the diminutive form of a word, e.g. prami/præm; b3di/b3d; doki/dog; $\theta_{\Lambda \mathrm{mzi}} / \theta_{\mathrm{Am}}$, which is interesting in terms of the theory of errors in aphasics being a reflection of acquisition in childhood. ${ }^{12,13}$

From the description of individual differences, the writer feels that what emerges as the differentiating factor between apraxics and the sensory aphasic $(\mathrm{Mr}$ $\mathrm{G})$ is not the distances between their errors and the target sound, but the fact that in the sensory aphasic the error of substitution is but one of many other characteristic errors, e.g. perseveration, whereas in the aphasic with apraxia of speech it is the major error. It is interesting to note, however, that aphasics with apraxia of speech, a so-called motor disorder, had poor scores on a test of oral stereognosis. This is perhaps an indication that the term sensori-motor would be more applicable.

\section{CONCLUSION}

It did not appear that aphasics with apraxia of speech were closer in distance to the target sound than sensory aphasics, as suggested by Canter ${ }^{4}$, These findings might have been the result of the more subtle analysis utilized in this study, i.e. a distinctive feature system. It seemed that the differentiating factor between the apraxics and the sensory aphasic was not distance, but frequency of other errors such as perseveration, reversals and verbal paraphasias in the Ss. The Ss with apraxia of speech made errors of substitution more frequently than other errors, while the sensory aphasic made as many substitution errors as those of perseveration, reversal, neologisms and augmentations.

It would seem that it is not possible to use distance as a method of diagnosing different types of aphasics. 


\section{REFERENCES}

1. Bay, E. (1964): Principles of Classification and their influence on our concepts of aphasia. In Disorders of Language. Ciba Foundation Symposium. de Reuck, A.V.S. \& O'Connor, M. (Eds.). Churchill Ltd., London.

2. Brain, Lord (1965): Speech Disorders (2nd Ed.) Butterworths, London.

3. Brown, J.W. (1972): Aphasia Apraxia and Agnosia: Clinical and Theoretical A spects. Charles C. Thomas, Springfield, Illinois.

4. Canter, G.J. (1969): The influence of primary and secondary verbal apraxia on output disturbances in aphasic syndromes. Paper presented to the annual convention of the American Speech and Hearing Assocition.

5. Canter, G.J. (1973): Dysarthria, apraxia of speech and literal paraphasia: three distinct varieties of articulatory behaviour in the adult with brain damage. Paper presented to the annual convention of the American Speech and Hearing Association.

6. Darley, F.L. (1964): Diagnosis and Appraisal of Communication Disorders. Prentice-Hall, Englewood Cliffs, N.J.

7. Darley, F.L. (1968): Apraxia of Speech: 107 years of terminological confusion. Paper presented to the annual convention of the American Speech and Hearing Association.

8. Darley, F.L. (1970): Apraxia of Speech: Definition, Description and Appraisal. Paper presented to the annual convention of the American Speech and Hearing Association.

9. Deal, J.L. \& Darley, F.L. (1972): The influence of linguistic and situational variables on phonemic accuracy in apraxia of speech. J. Speech Hear. Research. 15 (3) 639-653.

10. De Renzi, E.; Pieczuro, A.; \& Vignolo, L.A. (1966): Oral Apraxia and Aphasia. Cortex 2, 50-70.

11. Eisenson, J. (1973): Adult aphasia: Assessment and treatment. Appleton Century Crofts, New York.

12. Espir, M.L.E.; \& Rose, F.C. (1970): The basic neurology of speech. Salisbury Press, Oxford.

13. Fry, D.B. (1959): Phonemic substitutions in an Aphasic patient. Lang. \& Speech, 2, 52-61.

14. Goodglass, H. \& Kaplan, E. (1972): The Assessment of Aphasia and Related Disorders. Lea \& Febiger, Philadelphia.

15. Green, E. (1969): Phonological \& Grammatical Aspects of Jargon in an aphasic patient: A Case Study. Lang. and Speech 12, 103-118.

16. Hurwitz, L. (1974): A phonological Investigation of Jargon Aphasia. Unpublished Research Report, Department of Speech Pathology and Audiology, University of the Witwatersrand, Johannesburg.

17. Johns, D.F. \& Darley, F.L. (1970): Phonemic Variability in Apraxia of Speech. J. Speech Hear. Research. 13 (3), 556-583.

18. La Pointe, L.L. (1969): Phonemic Characteristics in apraxia of speech which aid in differentiation among articulation disorders in brain-injured adults. Paper presented to the American Speech and Hearing Association Convention.

19. Lecours, A.R. \& Lhermitte, E. (1969): Phonemic paraphasias: Linguistic Structures and Tentative Hypothesis. Cortex 5, 193-228. 
20. Luria, A.R. (1966): Higher Cortical Function in Man. Basic Books, New York.

21. Martin, A.D. (1974): Some objections to the term apraxia of speech. $J$. Speech Hear. Dis., 39 (1) 54-63.

22. Martin, A.D. \& Rigrodsky, S. (1974): An investigation of phonological impairment in Aphasia. Part I. Cortex 10 (4), 317-328.

23. Martin, A.D. \& Rigrodsky, S. (1974): An investigation of phonological impairment in Aphasia. Part II. Cortex 10 (4), 329-346.

24. Nathan, P.W. (1947): Facial Apraxia and Apraxic Dysarthria. Brain 70, 449.478.

25. Osgood, C.E. \& Miron, M.A. (1963): Approaches to the Study of Aphasia. University of Illinois Press, Urbana.

26. Rosenbek, J.C.; Lemme, M.L.; Ahern, M.B.; Harris, E.H. and Wertz, R.T. (1973): A treatment for Apraxia of Speech in Adults. J. Speech Hear. Dis., 38 (4), $462-472$.

27. Schane, S.A. (1973): Generative Phonology, Prentice Hall, Englewood Cliffs, New Jersey.

28. Schuell, H. (1965): Differential Diagnosis of Aphasia with the Minnesota Test, University of Minnesota Press, Minneapolis.

29. Shankweiler, D. and Harris, K.S. (1966): An experimental approach to the problem of articulation in aphasia. Cortex 2, 277-292.

30. Templin, M.C. \& Darley, F.L. (1960): The Templin-Darley Tests of Articulation. A manual and discussion of the screening and diagnostic tests. Bureau of Educational Research and Service Division of Extension and. University Services, University of Iowa, Iowa City, Iowa.

31. Thorndike, E. and Lorge, I. (1952): The Teacher's word book of 30,000 words. Bureau of Publications, Teachers College, Columbia University, N.Y.

32. Trost, J.E. and Canter, G.J. (1970): Subphonemic feature analysis of articulatory errors made by patients with verbal apraxia. Paper presented at the American Speech and Hearing. Association Convention.

33. Wertz, R.T. and Porch, B.E. (1970): Effects of masking noise on the verbal performance of adult aphasics. Cortex 6 (4), 399-408.

34. Wilson, A.K. (1908): A contribution to the study of apraxia. Brain 31, 164-216. 


\section{MODERN HEARING AIDS}

(PTY) LTD.

\section{FOR}

Hearing Aids - A comprehensive range comprising the latest Microson directional models - Unitron high level compression models - and Electone economically priced models.

Ear Moulds - We specialise in ear mould technology to the great benefit of our patients - we also supply instant mould kits to schools.

Audiometers - Audiotone portable screening and diagnostic units at the best prices available.

Sound Proof Booths and Earmuffs

High Quality locally manufactured products

TV accessories - manufactured by ourselves

\section{WE ARE AT}

305 Rand Central

165 Jeppe Str

Johannesburg

Tel: 23-9250

22-4855
133 Central House

and 288 Pretorius Str

Pretoria

Tel: 2-1206 